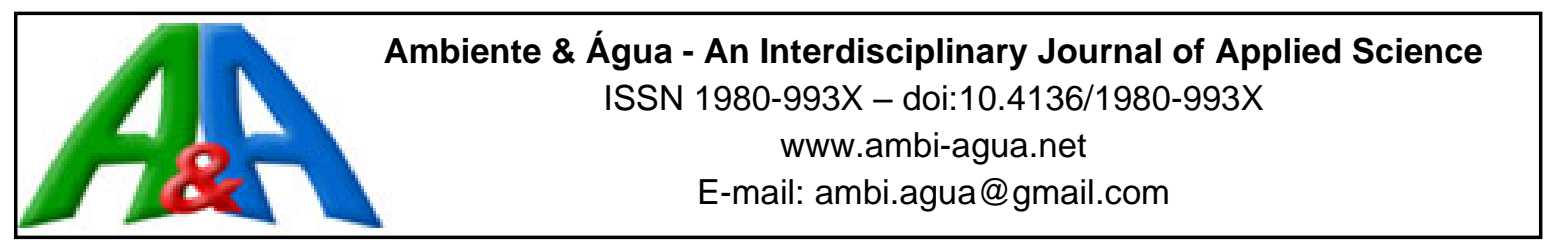

\title{
Furosemide in water matrix: HPLC-UV method development and degradation studies
}

\author{
ARTICLES doi:10.4136/ambi-agua.2406
}

Received: 19 Apr. 2019; Accepted: 30 Nov. 2019

\author{
Ana Isabel Machado ${ }^{*}$ (D); Rita Fragoso ${ }^{2}$; \\ Ana Vitória Martins Neves Barrocas Dordio ${ }^{3}{ }^{(D}$; Elizabeth Duarte $^{2}$ (D) \\ ${ }^{1}$ Linking Landscape, Environment, Agriculture and Food (LEAF). Marine and Environmental Sciences Centre \\ (MARE). Centre for Environmental and Marine Studies (CESAM). Higher Institute of Agronomy. University of \\ Lisbon, Tapada da Ajuda, s/n, CEP: 1349-017, Lisboa, Portugal \\ ${ }^{2}$ Linking Landscape, Environment, Agriculture and Food (LEAF), Higher Institute of Agronomy, University of \\ Lisbon, Tapada da Ajuda, s/n, CEP: 1349-017, Lisboa, Portugal. \\ E-mail: ritafragoso@isa.ulisboa.pt, eduarte@isa.ulisboa.pt \\ ${ }^{3}$ Marine and Environmental Sciences Centre (MARE). School of Science and Technology. Chemistry \\ Department. Évora University, Rua Romão Ramalho, nº 59, CEP: 7000-671, Évora, Portugal. \\ E-mail: avbd@uevora.pt \\ "Corresponding author. E-mail: isabellmachado@gmail.com
}

\begin{abstract}
This study developed a method for furosemide quantification through high performance liquid chromatographic technique. Special attention was given to solute loss and storage stability due to furosemide's low solubility and photosensitivity, respectively. The performance of Nylon and PVDF filters was tested in a $2 \mathrm{mg} . \mathrm{L}^{-1}$ furosemide solution. PVDF filters showed better recovery capacity and therefore are more suitable for furosemide filtration. Over eight days, three different storage conditions were studied to access furosemide degradation susceptibility: (i) exposure to light at room temperature, (ii) storage at room temperature without exposure to light, and (iii) storage at $4^{\circ} \mathrm{C}$ without exposure to light. The study demonstrated that after $48 \mathrm{~h}$ under natural light exposure furosemide was completely degraded. Furosemide solution stored in the dark was stable. Storage temperature did not seem to affect furosemide concentration. The study shows that the selection of more suitable filter and storage conditions for furosemide determination is crucial to avoid underestimation errors.
\end{abstract}

Keywords: filter retention, pharmaceutical, photodegradation.

\section{Furosemida em matriz de água: desenvolvimento de um método HPLC-UV e estudos de degradação}

\section{RESUMO}

O presente estudo desenvolve um método para a quantificação de furosemida através de cromatografia de alta resolução. Devido à baixa solubilidade do composto e à sua fotossensibilidade, neste estudo avaliou-se as possíveis perdas do composto ao longo do método de quantificação e a sua estabilidade durante o armazenamento ao longo de oito dias. Para tal, foram testados dois filtros (Nylon e PVDF) com o mesmo diâmetro e tamanho de poro para uma concentração de furosemida de $2 \mathrm{mg} . \mathrm{L}^{-1}$. A degradação da furosemida foi estudada para 
Ana Isabel Machado et al.

três condições diferentes de armazenamento: com exposição solar à temperatura ambiente, sem exposição solar à temperatura ambiente e sem exposição solar a $4^{\circ} \mathrm{C}$. O estudo demonstrou que o composto furosemida atinge a degradação completa com exposição solar após $48 \mathrm{~h}$. A solução de furosemida permaneceu estável ao longo da experiência quando protegida da luz. A temperatura de armazenamento não parece afetar a concentração da solução de furosemida. $\mathrm{O}$ presente estudo mostrou que para análises da furosemida, a escolha do filtro adequado e as condições de armazenamento devem ser consideradas para evitar erros de subestimação.

Palavras-chave: fármaco, foto degradação, retenção do filtro.

\section{INTRODUCTION}

The presence of pharmaceutical active compounds (PhACs) in different water bodies is well documented in several studies (Böger et al., 2018; Kuster et al., 2008; Paíga and DelerueMatos, 2016; Pereira et al., 2017). After ingestion, pharmaceuticals are only partially absorbed and the remainder is excreted as the parent compound or their metabolites via urine or feces. Conventional wastewater treatment processes are not completely efficient in removing $\mathrm{PhACs}$ (Ternes, 1998; Martín et al., 2012). Therefore, the development of methods to correctly quantify these compounds in specific matrices are required, and several options already exist. Environmental studies commonly determine the presence of PhACs in samples using methods for the determination of a broad variety of compounds (Cruz-Morató et al., 2014). Although this approach brings benefits such as reductions in time and cost, some inherent restrictions to the accuracy of the determination of each compound is associated, such as analyte loss due to membrane filter adsorption. HPLC-UV analyses requires samples to be filtered to avoid clogging the equipment and capillaries and to extend the column's lifespan (Carlson and Thompson, 2000). Moreover, compound stability studies are also necessary to prevent associated quantification errors, particularly along analyses procedures. For some pollutants, the knowledge of all interferences in the quantification process are still not fully known and require further investigation.

In Europe, anti-hypertensive substances, recently included in the cardiovascular system pharmacotherapeutic group, have the highest consumption rates (OECD, 2016). Included in this group, furosemide (FUR) is a loop diuretic pharmaceutical prescribed to treat cases of hypertension and edema (Bosch et al., 2008). In Portugal in 2014, FUR occupied the 15th place in the top 100 active substances ranking with the highest number of packages sold in the National Health System (INFARMED, 2014). According to Prandota and Witkowska (1976), after human consumption up to $70 \%$ of furosemide is absorbed. However, $90 \%$ of the nonabsorbed drug is excreted as the parent compound (Zuccato et al., 2005). Therefore, in countries such as Portugal, FUR is expected to be found in wastewater treatment plants (WWTPs) (Santos et al., 2013). According to the literature, the presence of FUR in WWTP influents and effluents can widely fluctuate from mg.L $\mathrm{L}^{-1}$ to ng. $\mathrm{L}^{-1}$ (Jelic et al., 2011; Salgado et al., 2010; Santos et al., 2013), while in surface water bodies it usually occurs in low concentrations of $\mu \mathrm{g} . \mathrm{L}^{-1}$ to ng. $\mathrm{L}^{-1}$ (Silva et al., 2011; Valcárcel, 2011; Matamoros et al., 2012).

Although several studies show the presence of FUR in different environmental samples, its concentration varies widely, inducing uncertainty in the $\mathrm{PhAC}$ relevance in terms of environment contamination and particularly in the accurate efficiency assessment of the WWTPs on removing this contaminant. Therefore, developing a quantification method for FUR that accounts for the different interferences that can exist along the analyses is vital. Moreover, the use of simple matrices such as ultrapure water for preliminary tests can provide more clear results, especially for compounds such as FUR that are hydrophobic and have low solubilities (Table 1), and thus are more prone to be lost during simple sample preparation procedures, such 
as filtration. Saturation of the filter adsorption sites generally can minimize these losses (Pillai et al., 2016). However, sometimes the sample volume is not enough for pre-wetting the filters, and thus the selection of the most suitable type of filter can be a key aspect.

Table 1. Structure, physical and chemical properties of furosemide.

\begin{tabular}{|c|c|c|}
\hline Common Name & Furosemide & \\
\hline \multicolumn{3}{|l|}{ Chemical structure } \\
\hline CAS-Number & $54-31-9$ & \\
\hline Molecular formula & $\mathrm{C}_{12} \mathrm{H}_{11} \mathrm{ClN}_{2} \mathrm{O}_{5} \mathrm{~S}$ & \\
\hline Molecular weight $\left(\right.$ g.mol $\left.^{-1}\right)$ & $330.75^{\mathrm{a}}$ & \\
\hline Melting Point $\left({ }^{\circ} \mathrm{C}\right)$ & $206^{\mathrm{a}}$ & \\
\hline Ionisation constant, pKa & $\mathrm{pKa}=3.8^{\mathrm{b}}$ & \\
\hline Octanol/Water Partition Coefficient, log Kow & $2.03^{\mathrm{c}}$ & \\
\hline Water solubility, at $30^{\circ} \mathrm{C}\left(\mathrm{mg} . \mathrm{L}^{-1}\right)$ & $73.1^{\mathrm{d}}$ & \\
\hline
\end{tabular}

Source: ${ }^{\mathrm{a}}$ O’Neil (2001). ${ }^{\mathrm{b}}$ Berthod et al. (1999). ${ }^{\mathrm{c}}$ Sangster (2001). ${ }^{\mathrm{d}}$ Yalkowsky and Dannenfelser (1992).

Another relevant factor is that the literature on methodologies for FUR quantification as a single target is only common in the scope of human or animal health, or for pharmaceutical dosage control (Bosch et al., 2008). Hence, most of the studies on FUR determination were performed in matrices of human and animal urine or plasma. The complexity of such matrices can mask other interferences along the analytical procedure.

This study sought to contribute to the definition of an appropriate methodology for FUR determination in a water matrix by HPLC-UV and to better understand the stability of the compound along the analysis-preparation procedure.

\section{MATERIALS AND METHODS}

\subsection{Chemicals and materials}

Analytical grade furosemide (99.8\% purity) was purchased from Sigma-Aldrich (Lisbon, Portugal); see Table 1 for its main characteristics. Phosphoric acid (>85\% purity), HPLC-grade solvents acetonitrile and methanol were obtained from Enzymatic, S.A. (Loures, Portugal). Ultra-pure water was prepared from a Millipore Milli Q system. Both Whatman 13 Puradisc syringe filters (nylon and PVDF - Polyvinylidene fluoride) were supplied by Enzymatic, S.A. (Loures, Portugal).

\subsection{Standards solutions}

Furosemide stock standard solution containing $10 \mathrm{mg} . \mathrm{L}^{-1}$ was prepared. Furosemide was dissolved in $1 \mathrm{ml}$ of methanol and filled to the $1 \mathrm{~L}$ mark with ultra-pure water. An ultrasonic bath was used to help the dissolution of furosemide. For furosemide quantification, standard solutions were prepared within the range of 0.1-4 mg. $\mathrm{L}^{-1}$. All solutions were stored in the dark and covered with aluminium foil to avoid photodegradation. The $10 \mathrm{mg} . \mathrm{L}^{-1}$ FUR solution was scanned between the 190 and $350 \mathrm{~nm}$ UV region. The wavelength of $233 \mathrm{~nm}$ corresponding to the maximum absorption peak has been therefore selected to carry on the experiment. Electric conductivity and $\mathrm{pH}$ were also assessed.

\subsection{Quantification and analytical method validation}

Furosemide quantification was carried out in a HPLC - Beckman Coulter System Gold, with a Solvent Module 126 and a Diode Array Detector 168, using 32 Karat Software, version 
8.0, with a variable wavelength detector $(190-800 \mathrm{~nm})$ at $233 \mathrm{~nm}$ and with a $20 \mu \mathrm{L}$ volume injector loop. Samples were determined with a flow rate of $1 \mathrm{~mL} \cdot \mathrm{min}^{-1}$. A reversed-phase analytical column Zorbax Eclipse XDB-C8 (4.6x150 mm; $5 \mu \mathrm{m})$ was used. The composition of the mobile phase used in furosemide analyses was previously selected for an isocratic elution mode using trial mixtures of acetonitrile and ultra-pure water acidified with phosphoric acid $(0.1 \% \mathrm{v} / \mathrm{v})$ in different proportions $(50: 50,55: 45,60: 40,65: 35$ and 70:30). The mixture composed of $60 \%$ acetonitrile and $40 \%$ ultra-pure water (acidified with phosphoric acid) was selected, as the corresponding retention time for furosemide was below 4 min., thereby allowing the quantification of the pharmaceutical in a reasonably short time. Samples were injected (three replicates) with an automatic injector manufactured by Spark Holland BV - MIDAS, at room temperature $\left(16-20^{\circ} \mathrm{C}\right)$.

This analytical method was validated according to the International Conference on Harmonization (ICH) guidelines for validation of analytical procedures (United States, 1996), based on the following parameters: linearity, sensitivity, precision (intra-day) and accuracy.

A calibration curve was constructed using a set of furosemide standard solutions with concentrations of 0.1-4 mg. $\mathrm{L}^{-1}$. Three replicate injections were made for each standard solution. The regression equation and the value of the correlation coefficient were calculated using linear regression analysis. The sensitivity of the analytical method was estimated in terms of the limits of detection (LOD) and of quantification (LOQ). LOD and LOQ were defined based on signalto-noise ratios of 3:1 and 10:1, respectively. Moreover, for the assessment of the analytical method's accuracy and precision (intra-day), standard solutions at seven different concentrations (from $0.25 \mathrm{mg} . \mathrm{L}^{-1}$ to $4 \mathrm{mg} . \mathrm{L}^{-1}$ ) were injected at three different times in the same day. The precision of the proposed method was obtained by calculating the relative standard deviation (RSD) values of the peak areas for the three different injections with acceptance criteria of not more than 2\% (United States, 1996). The accuracy of the quantification method was assessed through the percentage ratio between the measured concentrations of the furosemide standards and their nominal concentrations.

\subsection{Procedure}

Different syringe filters were tested to study the FUR recovery percentage throughout the process. Nylon and PVDF (Polyvinylidene fluoride), both with $0.45 \mu \mathrm{m}$ pore size as recommended for HPLC analysis, were selected. The filter size $(13 \mathrm{~mm})$ was chosen in accordance with the low sample volume required for further analysis. Through HPLC analysis, filter recovery capacity was tested for $2 \mathrm{mg} . \mathrm{L}^{-1}$ of FUR solution, filtering a volume of $2 \mathrm{~mL}$. Additionally, the recovery capacity was further validated comparing a standard curve, between 0.25 and $2 \mathrm{mg} . \mathrm{L}^{-1}$ of FUR, with and without filtration.

For FUR degradation studies, an experiment over 8 days was performed under three different storage conditions. At room temperature $\left(12-18^{\circ} \mathrm{C}\right)$, three replicates of a FUR solution with approximately $2 \mathrm{mg} . \mathrm{L}^{-1}$ were exposed to daylight (L), and the other three were kept in the dark (D) to test photodegradation sensitivity. The effect of storage temperature was tested with another three replicates that were kept at $4^{\circ} \mathrm{C}$. Samples were taken from all the standard solutions after 0, 24, 48, 72 and 192 hours of exposure and analysed through HPLC.

\section{RESULTS AND DISCUSSION}

\subsection{Furosemide quantification}

\subsubsection{Furosemide recovery}

Figure 1 compares the extent of FUR retention by two different filters, Nylon and PVDF, for the same solution. Nylon filters presented $75 \%$ more FUR adsorption than PVDF filters. 
Hence, the PVDF filter seems more efficient for FUR solution filtration. Several factors can affect adsorption onto membranes, from characteristics of the compounds to the properties of the filters. Both filters have hydrophilic membranes, the same pore size $(0.45 \mu \mathrm{m})$ and the same effective filter area $\left(1.3 \mathrm{~cm}^{2}\right)$. Nylon filters, compared with PVDF, bind proteins and are more suitable for filtering samples with a high $\mathrm{pH}$. In turn, PVDF filters are highly inert and have low protein binding (GE Healthcare, 2018). Since the standard samples have a $\mathrm{pH}$ of $5.5 \pm 0.17$, both filters were appropriate. Hence, the results can be an outcome of the inert feature of the PVDF filters. To further validate the PVDF filters' suitability, a comparison of a standard curve with and without filtration was performed (see Figure 2). No significant losses were observed. Therefore, the PVDF filter was considered appropriate to carry on experiments with FUR.

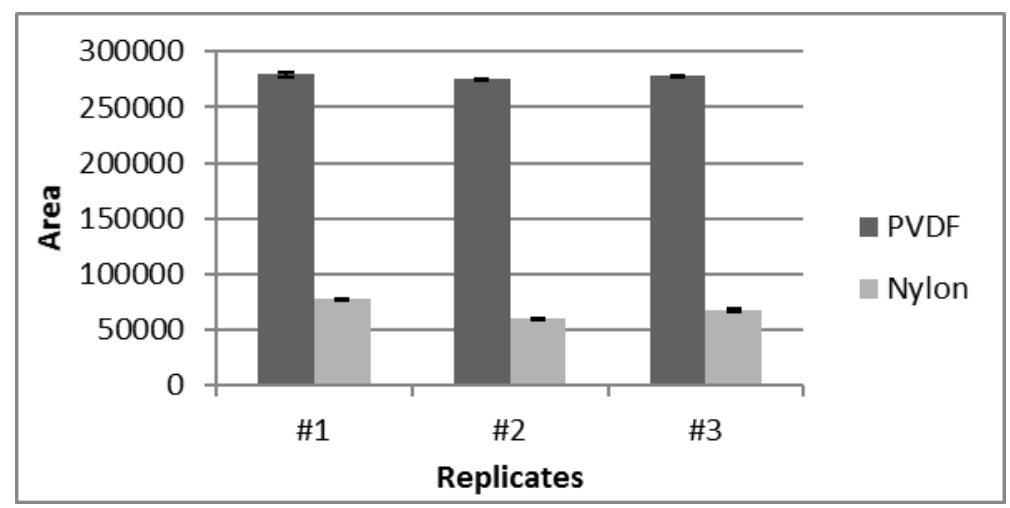

Figure 1. FUR retention (2 mg. $\left.\mathrm{L}^{-1}\right)$ in Nylon and PVDF filters.

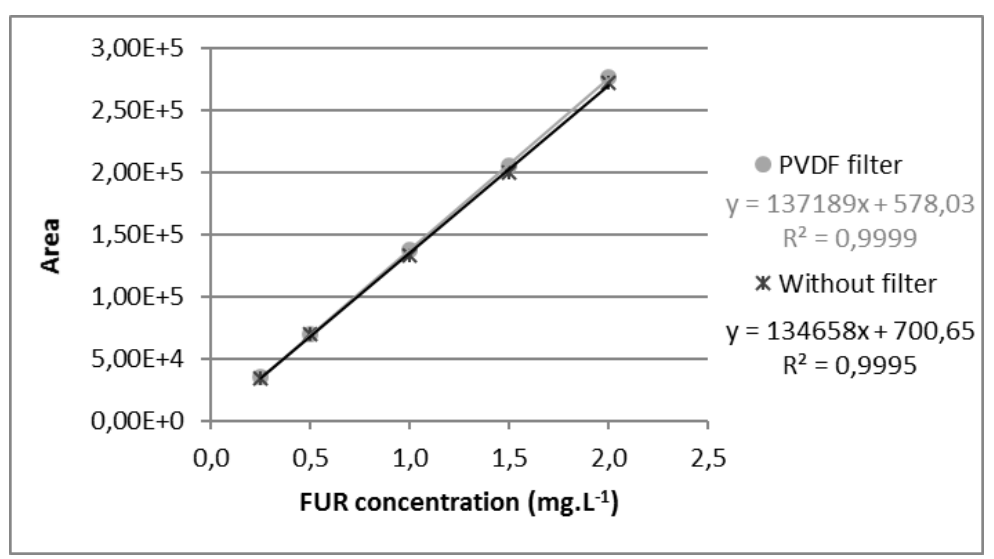

Figure 2. Standard curve of FUR for samples without filtration and filtered through PVDF filters.

\subsubsection{Method validation}

An optimal peak shape and retention time of FUR was obtained for the selected chromatographic conditions (Figure 3). The method employed also showed a linear pattern for the tested concentration range $\left(0.1-4.0 \mathrm{mg} . \mathrm{L}^{-1}\right)$ with a correlation $\mathrm{r}^{2}=0.9999$ (Figure 4). Limit of quantification (LOQ) was $0.144 \mathrm{mg} . \mathrm{L}^{-1}$ and limit of detection (LOD) was $0.048 \mathrm{mg} . \mathrm{L}^{-1}$ (Equations 1 and 2, respectively). The accuracy of the method was estimated to be within 93.7$101.8 \%$, whereas in regard to the intra-day precision, RSD of measurements were below $2 \%$. Therefore, the method can be considered to provide a good sensitivity, precision and accuracy.

$$
\begin{aligned}
& L O Q=\frac{10 \times \sigma}{\text { slope of calibration curve }} \\
& L O D=\frac{3.3 \times \sigma}{\text { slope of calibration curve }}
\end{aligned}
$$




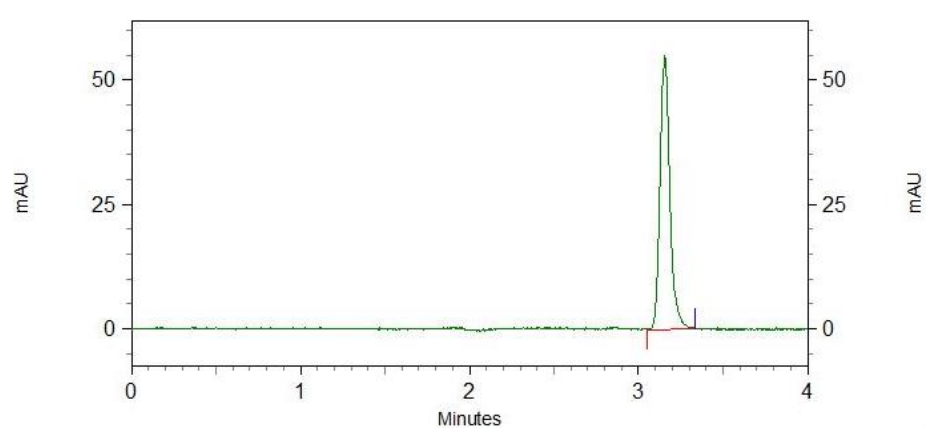

Figure 3. Chromatogram of FUR in ultrapure water matrix.

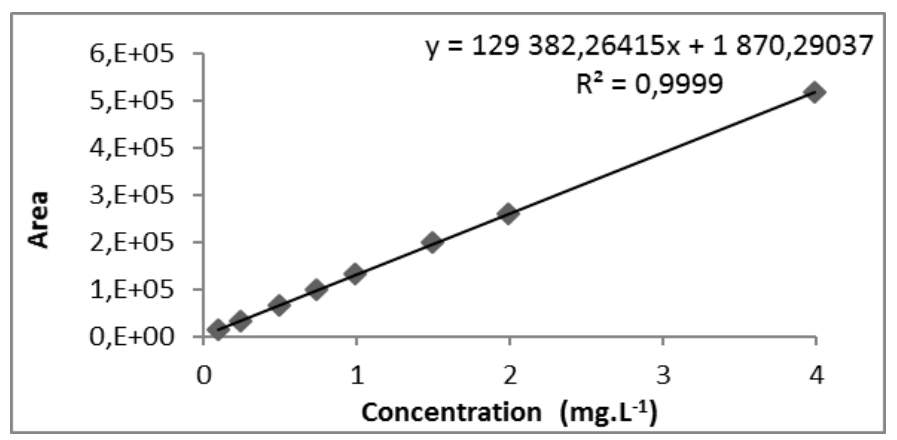

Figure 4. Linearity of FUR in an ultrapure water matrix.

\subsection{Degradation studies}

Figure 5 shows FUR stability over 8 days under different storage conditions. The FUR solutions kept from light exposure maintained their concentration throughout the experiment. Storage temperature does not seem to affect FUR concentration. Moreover, since FUR quantification is performed at room temperature, FUR-solution storage should benefit if similar temperatures are maintained to avoid potential precipitation. Figure 5 shows that during the first $24 \mathrm{~h}$ of exposure there is a slight increase in concentration in 4D solutions. The minor increase is due to the initial lower values of one of the replicates. Poor initial solubility of the replicate could explain the lower value at 0 hours of exposure, compared to the 24-hour sample.

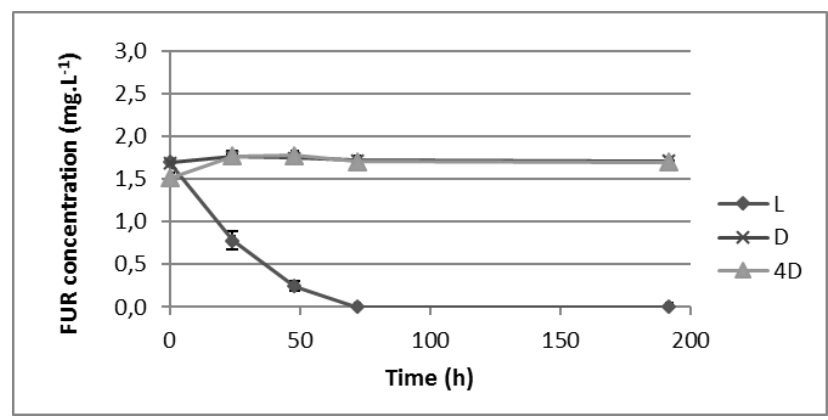

Figure 5. FUR conservation over 8 days for three different conditions: L - Light exposure at room temperature; D - Kept in the dark at room temperature; and, $4 \mathrm{D}-\mathrm{Kept}$ in the dark at $4^{\circ} \mathrm{C}$.

FUR's sensitivity to light is well-documented, and the appearance of photodegradation products as a result of the exposure to light is to be expected (Greca et al., 2004). In fact, Figure 6a shows the presence of two new peaks ( 2 and 3 ) along with the peak of FUR (1). Substance (3) appears in all samples after $24 \mathrm{~h}$ and disappears before $48 \mathrm{~h}$ of exposure; therefore, light exposure and temperature are not the key factors to explain this phenomenon. Moreover, substance (3) seems to suffer further degradation since it disappears after $48 \mathrm{~h}$. 
In the first $72 \mathrm{~h}$ of exposure, the decrease of FUR is followed by an increase of the concentration of substance (2). Afterwards, substance (2) decreases to concentrations below detection levels. Greca et al., (2004) tested the photodegradation of furosemide in different water matrices through a $150-\mathrm{W}$ solar simulator over $36 \mathrm{~h}$. In all water matrices, including a simple distilled water medium, only one new photoproduct was found. The same result occurred when the distilled water solution was exposed to natural solar radiation. Therefore, the main photoproduct mentioned above, substance (2), which is visible in the solution exposed to light, can be the same as the one found in the previously referred to work. FUR, in aqueous solutions exposed to UV light, hydrolyses into 2-amino-4-chloro-5 sulfamoylanthranilic acid (CSA) and furfuryl alcohol that will be further degraded into levulinic acid (Ruiz-Angel et al., 2006). Therefore, substance (2) could be the FUR photoproduct CSA, but further liquid chromatography mass spectrometry analysis should be undertaken for substance identification (Figure 7).

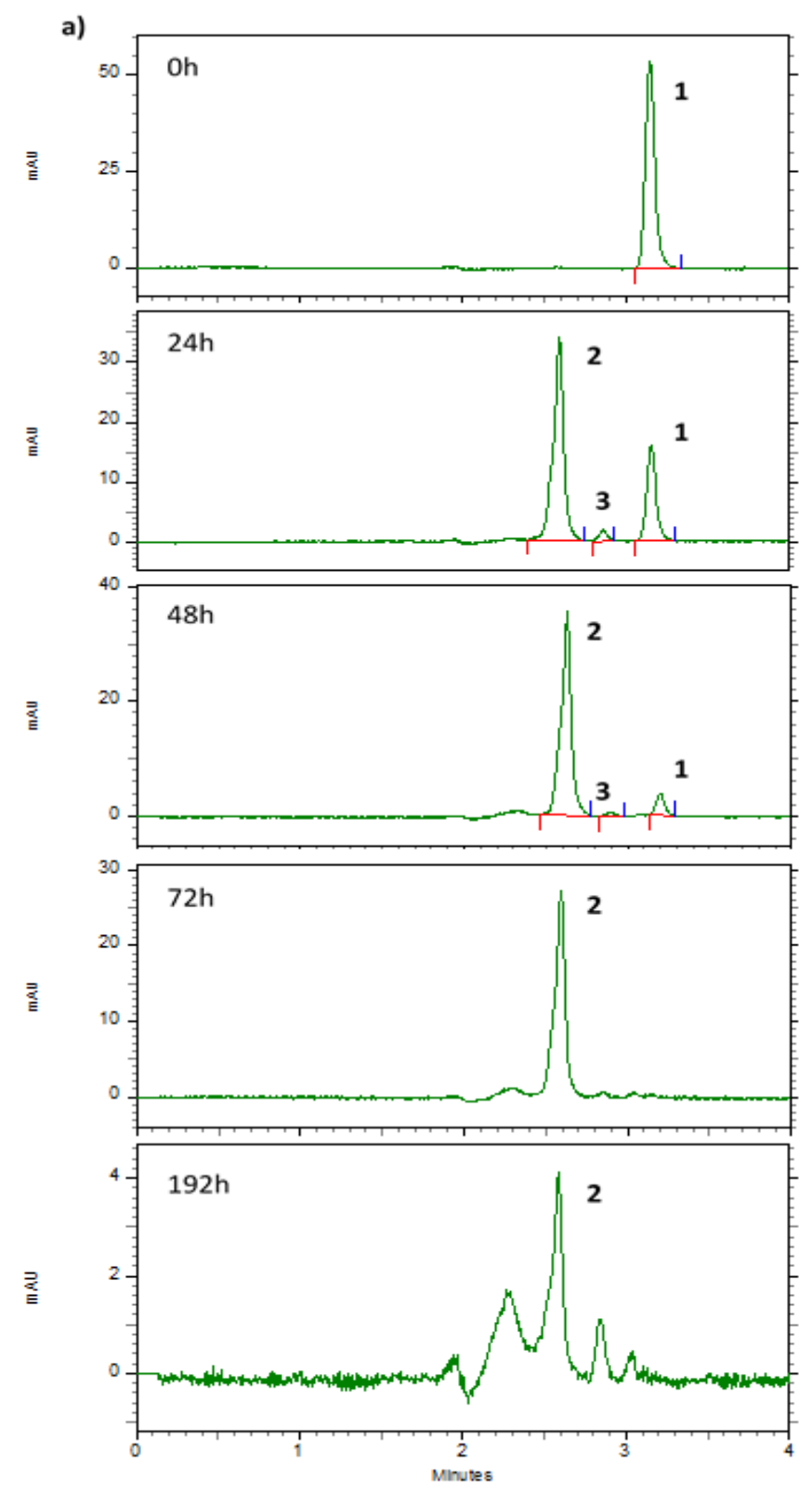

Figure 6. Chromatogram of furosemide in ultrapure water under: a) light exposure/room temperature; b) darkness/room temperature; c) darkness $/ 4^{\circ} \mathrm{C}$. Continue. 
b)
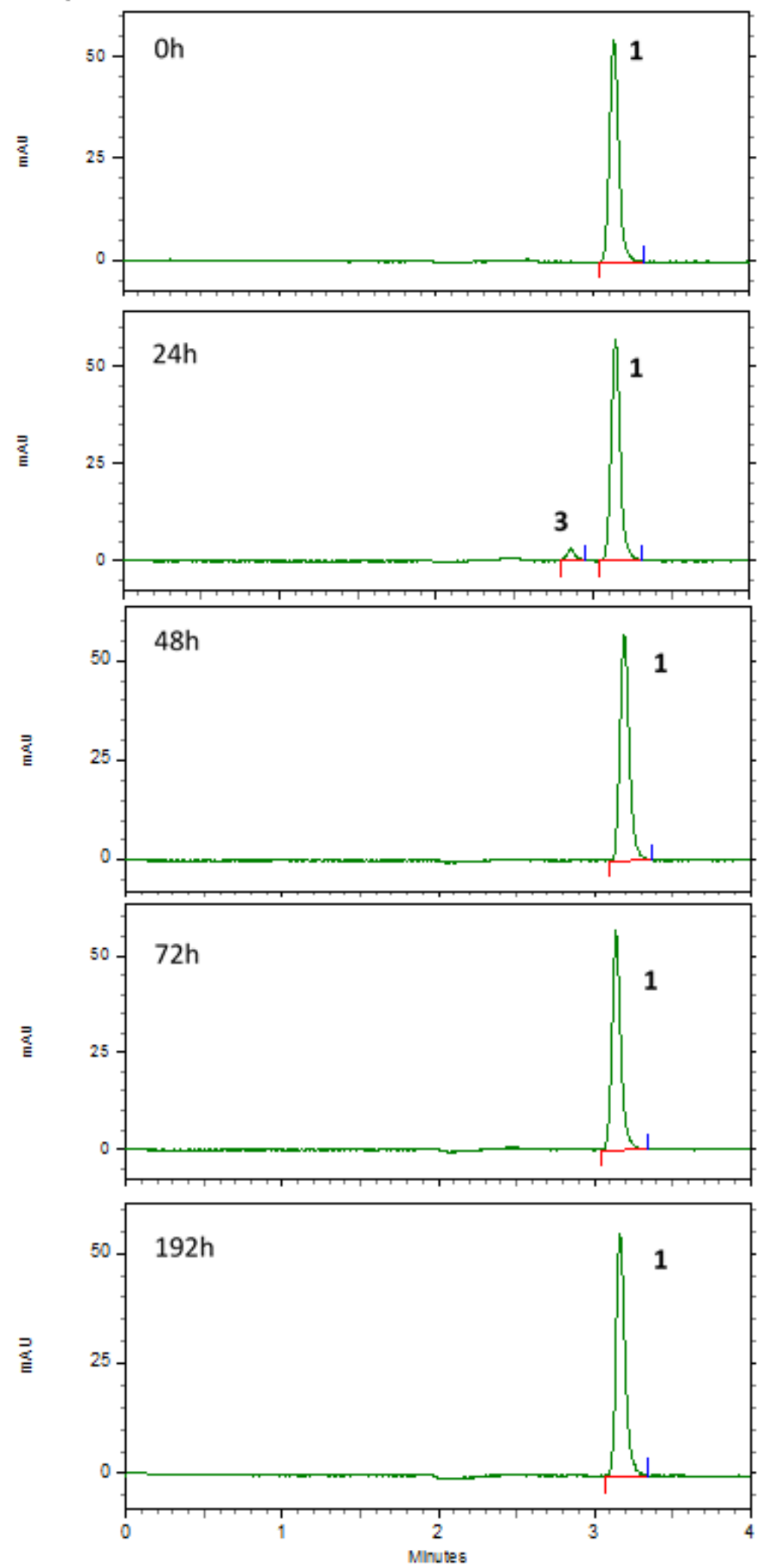

Figure 6. Continue. 
c)
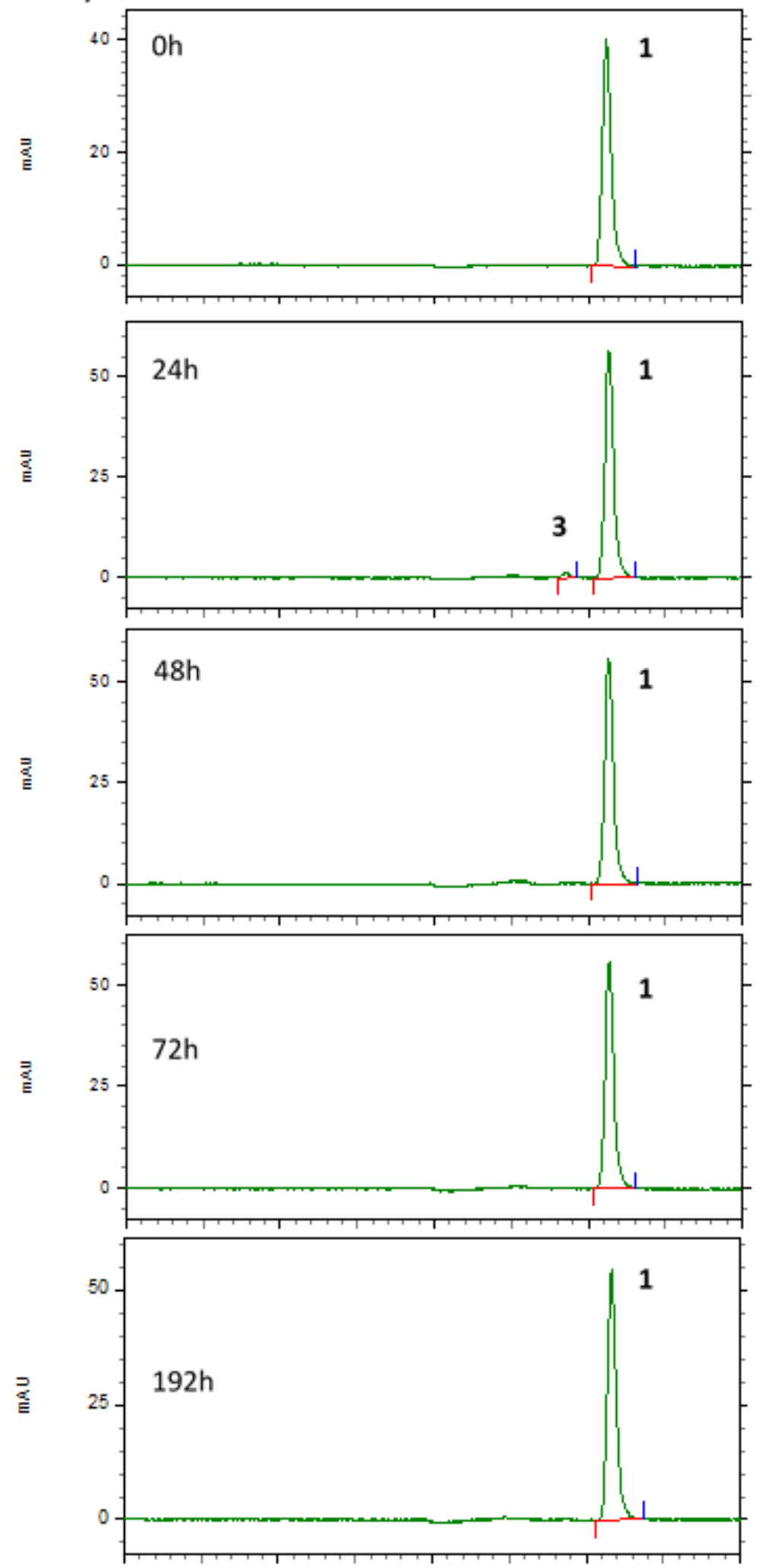

Figure 6. Continue. 

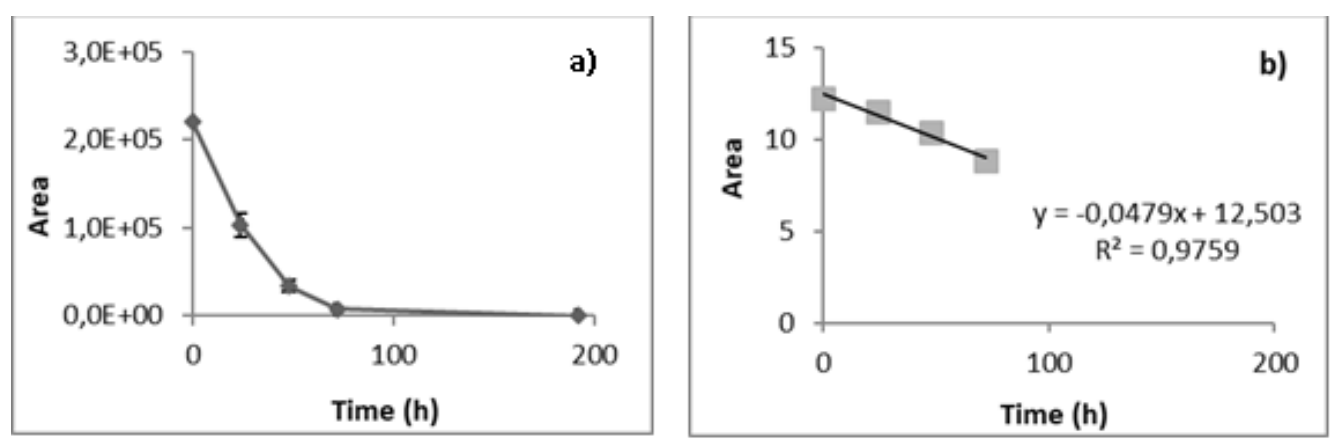

Figure 7. a) Furosemide photodegradation over eight days; b) First-order kinetic of furosemide photodegradation.

\section{CONCLUSIONS}

The developed method allows fast and accurate determination of FUR in water solution by HPLC-UV. In the 0.1-4 mg. $\mathrm{L}^{-1}$ concentration range, the quantification of FUR follows a linear regression. Due to its low solubility and sorption susceptibility, FUR standard solutions should be filtered through PVDF filters or others with a similar inert feature. Stability studies validated the well-known photo sensitivity characteristic of FUR. Total photodegradation of a FUR solution was achieved after $48 \mathrm{~h}$ of exposure to natural light. Therefore, it is recommended that FUR standards solutions should be stored in the dark at room temperature to guarantee concentration conservation. The study emphasizes that when targeting FUR in low volume environmental samples, special attention should be given to the chosen filter, as well as to storage conditions to avoid underestimation errors.

\section{ACKNOWLEDGEMENTS}

The present study was supported by the FCT - Fundação para a Ciência e a Tecnologia (doctoral grant SFRH/BD/52511/2014), inserted in the doctoral program FCT-FLUVIO and River Restoration and Management (Reference: PD/00424/2012). A special thanks to researcher Antonio Eduardo Leitão for access to HPLC-UV equipment.

\section{REFERENCES}

BERTHOD, A.; CARDA-BROCH, S.; GARCIA-ALVAREZ-COQUE, M. C. Hydrophobicity of Ionizable Compounds. A theoretical study and measurements of diuretic octanol-water partition coefficients by countercurrent chromatography. Analytical Chemistry, v. 71, p. 879-888, 1999. http://dx.doi.org/10.1021/ac9810563

BÖGER, B.; AMARAL, B.; SILVEIRA, P. L.; WAGNER, R.; PERALTA-ZAMOR, P. G.; GOMES, E. C. Determination of carbamazepine and diazepam by SPE-HPLC-DAD in Belém river water, Curitiba-PR/Brazil. Revista Ambiente \& Água, v. 13, n. 2, 2018. http://dx.doi.org/10.4136/ambi-agua.2196

BOSCH, M. E.; SANCHEZ, A. J. R.; ROJAS, F. S.; OJEDA, C. B. Recent developments in analytical determination of furosemide, Journal of Pharmaceutical and Biomedical Analysis, v. 48, p. 519-532, 2008. http://dx.doi.org/10.1016/j.jpba.2008.07.003

BUNDGAARD, H.; NØRGAARD, T.; MØRKNIELSEN, N. Photodegradation and hydrolysis of furosemide and furosemide esters in aqueous solutions. International Journal of Pharmaceutics, v. 42, n. 1-3, p. 217-224, 1988. https://doi.org/10.1016/03785173(88)90178-0 
CARLSON, M.; THOMPSON, R. D. Analyte Loss Due to Membrane Filter Adsorption as Determined by High-Performance Liquid Chromatography. Journal of $\begin{array}{llllll}\text { Chromatographic } & \text { Science, } & \text { v. } & 38, & \text { p. } & 78-83,\end{array}$ https://doi.org/10.1093/chromsci/38.2.77

CRUZ-MORATÓ, C.; LUCAS, D.; LLORCA, M.; RODRIGUEZ-MOZAZ, S.; GORGA, M.; PETROVIC, M.; BARCELÓ, D.; VICENT, T.; SARRÀ, M.; MARCO-URREA, E. Hospital wastewater treatment by fungal bioreactor: Removal efficiency for pharmaceuticals and endocrine disruptor compounds. Science of the Total $\begin{array}{lllll}\text { Environment, } & \text { v. } & 493, & \text { p. } & 365-376,\end{array}$ http://dx.doi.org/10.1016/j.scitotenv.2014.05.117

GE HEALTHCARE. Digizuite. 2018. Available at: https://cdn.gelifesciences.com/dmm3bwsv3/AssetStream.aspx?mediaformatid=10061\& destinationid=10016\&assetid=16239. Access: April $18^{\text {th }}, 2018$.

GRECA, M. D.; IESCE, M. R.; PREVITERA, L.; RUBINO, M.; TEMUSSI, F. A new photoproduct of the drug furosemide in aqueous media. Environmental Chemistry Letters, v. 2, p. 155-158, 2004. http://dx.doi.org/10.1007/s10311-004-0080-9

INFARMED. Estatística do Medicamento. 2014. Available at: https://www.infarmed.pt/documents/15786/1229727/Estat\%C3\%ADstica+do+Medicament o+2014/988074f4-4f89-4a7c-9055-844cb88e93fd?version=1.2 Access: April 18 ${ }^{\text {th }}, 2018$.

JELIC, A.; MERITXELL, G.; GINEBREDA, A.; CÉSPEDES-SÁNCHEZ, R.; VENTURA, F.; PETROVIC, M.; BARCELO, D. Occurrence, partition and removal of pharmaceuticals in sewage water and sludge during wastewater treatment. Water Research, v. 45, n. 3, p. 1165-1176, 2011. https://doi.org/10.1016/j.watres.2010.11.010

KUSTER, M.; LÓPEZ, J.; DE ALDA, M.; HERNANDO, M. D.; PETROVIC, M.; MARTINALONSO, J.; BARCELÓ, D. Analysis and occurrence of pharmaceuticals, estrogens, progestogens and polar pesticides in sewage treatment plant effluents, river water and drinking water in the Llobregat river basin (Barcelona, Spain). Journal of Hydrology, v. 358, p. 112-123, 2008. http://doi.org/10.1016/j.jhydrol.2008.05.030

MARTÍN, J.; CAMACH-MUÑOZ, D.; SANTOS, J. L.; APARICIO, I.; ALONSO, E. Occurrence of pharmaceutical compounds in wastewater and sludge from wastewater treatment plants: Removal and ecotoxicological impact of wastewater discharges and sludge disposal. Journal of Hazardous Materials, v. 239-240, p. 40-47, 2012. http://dx.doi.org/10.1016/j.jhazmat.2012.04.068

MATAMOROS, V.; ARIAS, C. A.; NGUYEN, L. X.; SALVADÓ, V.; BRIX, H., 2012. Occurrence and behavior of emerging contaminants in surface water and a restored $\begin{array}{lllll}\text { wetland. Chemosphere, } & \text { v. } & \text { v. 88, p. 1083-1089, }\end{array}$ http://dx.doi.org/10.1016/j.chemosphere.2012.04.048

O'NEIL, M. J. (ed.). The Merck Index - An Encyclopedia of Chemicals, Drugs, and Biologicals. 13th Ed. Whitehouse Station: Merck and Co., 2001.

OECD. Demographic references: General demographics. 2016. Available online at https://stats.oecd.org/Index.aspx?DataSetCode=HEALTH_DEMR. Access: Feb. 14th 2018.

PAÍGA, P.; DELERUE-MATOS, C. Determination of pharmaceuticals in groundwater collected in five cemeteries' areas (Portugal). Science of the Total Environment, v. 569-570, p. 16-22, 2016. http://dx.doi.org/10.1016/j.scitotenv.2016.06.090 
PEREIRA, A. M. P. T.; SILVA, L. J. G.; LARANJEIRO, C. S. M.; MEISEL, L. M.; LINO, C. M.; PENA, A. Human pharmaceuticals in Portuguese rivers: The impact of water scarcity in the environmental risk. Science of the Total Environment, v. 609, p. 1182-1191, 2017. https://doi.org/10.1016/j.scitotenv.2017.07.200

PILLAI, S.A.; CHOBISA, D.; URIMI, D.; RAVINDRA, N. Filters and Filtration: A Review of Mechanisms That Impact Cost, Product Quality and Patient Safety. Journal of Pharmaceutical Sciences and Research, v. 8, n. 5, p. 271-278, 2016.

PRANDOTA, J.; WITKOWSKA, M., Pharmacokinełics and mełabolism of furosemide in man. European Journal of Drug Metabolism and Pharmacokinetics, v. 4, p. 177-181, 1976. http://dx.doi.org/10.1007/BF03189275

RUIZ-ANGEL, M. J.; BERTHOD, A.; CARDA-BROCH, S.; GARCÍA-ÁLVAREZ-COQUE, M. C. Analytical Techniques for Furosemide Determination. Separation \& Purification Reviews v. 35, n. 2, p. 39-58, 2006. https://doi.org/10.1080/15422110600671726

SALGADO, R.; NORONHA, J. P.; OEHMEN, A.; CARVALHO, G.; REIS, M. A. M. Analysis of 65 pharmaceuticals and personal care products in 5 wastewater treatment plants in Portugal using a simplified analytical methodology. Water Science and Technology, v. 62, n. 12, p. 2862-2871, 2010. http://dx.doi.org/10.2166/wst.2010.985

SANGSTER, J. LOGKOW Databank. Montreal Quebec: Sangster Res. Lab., 2001.

SANTOS, L. H. M. L. M.; GOS, M.; RODRIGUEZ-MOZAZ, S.; DELERUE-MATOS, C.; PENA, A.; BARCELÓ, D.; MONTENEGRO, M. C. B. S. M. Contribution of hospital effluents to the load of pharmaceuticals in urban wastewaters: Identification of ecologically relevant pharmaceuticals. Science of the Total Environment, v. 461-462, p. 302-316, 2013. http://dx.doi.org/10.1016/j.scitotenv.2013.04.077

SILVA, B. F.; JELIC, A.; LÓPEZ-SERNA, R.; MOZETO, A. A.; PETROVIC, M.; BARCELÓ, D. Occurrence and distribution of pharmaceuticals in surface water, suspended solids and sediments of the Ebro river basin, Spain. Chemosphere, v. 88, n. 8, p. 1331-1339, 2011. https://doi.org/10.1016/j.chemosphere.2011.07.051

TERNES, T. A. Occurrence of drugs in german sewage treatment plants and rivers. Water Research, v. 32, n. 11, p. 3245-3260, 1998. https://doi.org/10.1016/S00431354(98)00099-2

UNITED STATES. Food and Drug Administration. ICH Q1B: Photostability testing of new drug substances and products. Washington, 1996.

VALCÁRCEL, Y.; GOLZÁLEZ ALONSO, S.; RODRÍGUEZ-GIL, J. L.; ROMO MAROTO, R.; GIL, A.; CATALÁ, M. Analysis of the presence of cardiovascular and analgesic/antiinflammatory/antipyretic pharmaceuticals in river- and drinking-water of the Madrid Region in Spain. Chemosphere, v. 82, p. 1062-1071, 2011. http://dx.doi.org/10.1016/j.chemosphere.2010.10.041

YALKOWSKY, S. H.; DANNENFELSER, R. M. Aquasol Database of Aqueous Solubility. 5th ed. Tucson: College of Pharmacy, University of Arizona, 1992.

ZUCCATO, E.; CASTIGLIONI, S.; FANELLI, R. Identification of pharmaceuticals for human use contaminating the Italian aquatic environment. Journal of Hazardous Materials, $v$. 122, p. 205-209, 2005. http://dx.doi.org/10.1016/j.jhazmat.2005.03.001 